\title{
MICROSTRUCTURAL EVOLUTION AND MECHANICAL CHARACTERIZATIONS OF AL-TiC MATRIX COMPOSITES PRODUCED VIA FRICTION STIR WELDING
}

\author{
KARAKTERIZACIJA RAZVOJA MIKROSTRUKTURE IN \\ MEHANSKIH LASTNOSTI KOMPOZITA Al-TiC IZDELANEGA \\ $S$ TORNIM VARJENJEM Z MEŠANJEM
}

\author{
Oluwatosin Olayinka Abegunde, Esther Titilayo Akinlabi, Daniel Madyira \\ University of Johannesburg, Faculty of Engineering and Built Environment, Department of Mechanical Engineering Science, \\ Auckland Park Kingsway Campus, 2006 Johannesburg, South Africa \\ oabegunde@uj.ac.za \\ Prejem rokopisa - received: 2016-02-09; sprejem za objavo - accepted for publication: 2016-03-21
}

doi:10.17222/mit.2016.033 A study was conducted on the material characterization of aluminium (Al) and titanium carbide (TiC) metal-matrix composites
produced via friction stir processing. Different process parameters were employed for the welding process. Rotational speeds of
$1600 \mathrm{~min}^{-1}$ to $2000 \mathrm{~min}^{-1}$, at an interval of $200 \mathrm{~min}^{-1}$ and traverse speeds of $100 \mathrm{~mm} / \mathrm{min}$ to $300 \mathrm{~mm} / \mathrm{min}$, at an interval of 100
$\mathrm{~mm} / \mathrm{min}$ were employed for the welding conducted on an Intelligent Stir Welding for Industry and Research (I-STIR) Process
Development System (PDS) platform. The characterizations carried out include light microscopy and the scanning electron
microscopy analyses combined with Energy-Dispersive Spectroscopy (SEM/EDS) techniques to investigate the particle
distribution, microstructural evolution and the chemical analysis of the welded samples. Vickers microhardness tests were used
to determine the hardness distribution of the welded zone and tensile testing was conducted to quantify the strength of the
welded area compared to the base metal in order to establish the optimal process parameters. Based on the results obtained from
the characterization analysis, it was found that the process parameters played a major role in the microstructural evolution. A
homogenous distribution of the TiC particles was observed at a high rotational speed of 2000 min ${ }^{-1}$ and a low traverse speed of
$100 \mathrm{~mm} / \mathrm{min}$. The highest hardness value was measured at the stir zone of the weld due to the presence of the TiC reinforcement
particles. The tensile strength also increased as the rotational speed increased and $92 \%$ joint efficiency was recorded in a
sample produced at 2000 min
in the stir zone. The optimum process parameter setting was found to be at $2000 \mathrm{~min}^{-1}$ and $100 \mathrm{~mm}$ min and can be
recommended. carbide

V tem raziskovalnem delu je bila izvedena obsežna študija karakterizacije kovinskega kompozita aluminija (Al ) in titanovega karbida (TiC) izdelanega $\mathrm{z}$ mešalno tornim varjenjem. Za postopek varjenja so bili uporabljeni različni procesni parametri. Rotacijski hitrosti $1600 \mathrm{~min}^{-1}$ do $2000 \mathrm{~min}^{-1}$, v razmaku po $200 \mathrm{~min}^{-1}$, in prečnih hitrostih od $100 \mathrm{~mm} / \mathrm{min} \mathrm{do} 300 \mathrm{~mm} / \mathrm{min}$, v intervalu $100 \mathrm{~mm} / \mathrm{min}$, je bilo uporabljeno za varjenje na industrijski platformi za razvoj in raziskave (PDS) sistema inteligentnega varjenja $\mathrm{z}$ mešanjem (I-Stir). Izvedena karakterizacija vključuje svetlobno mikroskopijo in vrstično elektronsko mikroskopijo v kombinaciji z energijo disperzijsko spektroskopijo (SEM/EDS), za preiskavo porazdelitve delcev, razvoja mikrostrukture in kemijsko analizo zvarjenih vzorcev. Za določitev optimalnih procesnih parametrov je bil uporabljen Vickers preizkus mikrotrdote, s katerim je bila določena porazdelitev trdote na področju zvara, $\mathrm{z}$ nateznim preizkusom pa je bila določena trdnost zvara v primerjavi z osnovnim materialom. Na osnovi rezultatov, dobljenih z analizo, je bilo ugotovljeno, da so procesni parametri igrali pomembno vlogo pri razvoju mikrostrukture. Homogena porazdelitev TiC delcev je bila opažena pri visokih hitrostih vrtenja $\left(2000 \mathrm{~min}^{-1}\right)$ in nizki prečni hitrosti $(100 \mathrm{~mm} / \mathrm{min})$. Največja vrednost trdote je bila izmerjena v mešaln coni zvara zaradi prisotnosti delcev TiC za ojačanje. Natezna trdnost se je povečala tudi pri povečanju hitrosti vrtenja in $92 \%$ skupne učinkovitosti spoja je bila zabeležena pri vzorcu, izdelanem pri $2000 \mathrm{~min}^{-1}$ in prečni hitrosti $100 \mathrm{~mm} / \mathrm{min}$. EDS-analiza je pokazala, da Al, Ti in C povzročijo sestavo kompozita, ki je nastal v področju mešanja. Priporočljiva in optimalna nastavitev procesnih parametrov je $2000 \mathrm{~min}^{-1}$ in prečna hitrost $100 \mathrm{~mm} / \mathrm{min}$.

Ključne besede: aluminij, torno varjenje z mešanjem, mehanske lastnosti, kompozit s kovinsko osnovo, mikrostruktura, titan karbid

\section{INTRODUCTION}

Metal-matrix composites (MMCs) reinforced with ceramic phases exhibit high stiffness, high elastic modulus, improved resistance to wear, creep and fatigue, which make them promising structural materials for the aerospace and automobile industries compared to monolithic metals. However, these composites also suffer from a significant loss in ductility and toughness due to the incorporation of non-deformable ceramic reinforcements, which limit their application, especially where the ductility of the material is a determinant factor in the material selection. ${ }^{1}$ Aluminium metal-matrix composites (AMCs) are variants of MMCs that have the potential to replace many conventional engineering materials. AMCs have already found commercial applications in the defence, aerospace, automobile and the marine industries due to their favourable metallurgical and mechanical 
properties..$^{2-5}$ The metal matrix is aluminium, while the reinforcement can be any ceramic particles compatible with the metal matrix.

In recent years, several techniques have been reported for manufacturing AMCs, these include; plasma air spraying, stir casting, squeeze casting, molten metal infiltration and powder metallurgy. These techniques have been reported for producing bulk composites, while high-energy laser melt injection, plasma spraying, cast sinter and electron beam irradiation have been used for producing surface AMCs. ${ }^{6,7}$ Nevertheless, it should be pointed out that most of these existing processing techniques for forming composites are generally based on liquid-phase processing at high temperatures. In this case, it is hard to avoid the interfacial reaction between the reinforcement and the metal matrix and the formation of some detrimental phases. ${ }^{1}$

Friction stir welding (FSW) is a solid-state welding process developed by TWI for welding aluminium and its alloys. ${ }^{8}$ It has been used to successfully weld aluminium alloys ${ }^{9-11}$ and also used to weld other metals like magnesium, copper and titanium. ${ }^{12-14}$ FSW is an emerging potential technique that can be employed for producing AMCs. ${ }^{15-18}$ Since the process is a solid-state welding process, it is envisaged to alleviate the problems associated with interfacial reaction, the melting of ceramics and the formation of detrimental phases during the manufacture of AMCs.

Research studies have been reported on the friction stir processing (FSP) of aluminium matrix composites. ${ }^{19-22}$ These studies concluded that grain refinement was achieved using the FSP process. An improved particle distribution and better mechanical properties were also observed. Also reported is that the process parameters used for welding and the tool geometry played a major role in the final outcome. Based on the available literature, previous research studies have been limited to surface composites using the FSP process for a modification of the surface properties.

In this study, AMCs were produced using FSP and titanium carbide $(\mathrm{TiC})$ particles were used as the reinforcement. The addition of the $\mathrm{TiC}$ ceramic particles is due to its favourable mechanical properties, which include a high melting point, favourable fracture and tribological properties. The preference of FSP for the production of Al-TiC composite is to avoid delamination (a failure when laminated material becomes separated, perhaps due to poor processing during production, impact on service, or some other factors that may lead to the separation of layers of reinforcement), debonding (when two materials stop adhering to each other), incompatible mixing of base materials and filler materials, the presence of porosity, inhomogeneous distribution (clustering), the segregation of grains at boundaries, the wetting of the particles, excess eutectic formation, melting of ceramic particles and the formation of undesirable deleterious phase usually experienced in other techniques. FSP is also advantageous due to the rapid removal of reaction products from the interface, which enhances further reaction

The effect of process parameters on the stir zone's microstructure, microhardness and tensile behaviour was studied and the optimal process parameters were established.

\section{EXPERIMENTAL PART}

\subsection{Preparation, dimensions and composition of work- pieces}

Aluminium 1050 alloy sheets of dimensions $300 \mathrm{~mm}$ $\times 200 \mathrm{~mm} \times 3 \mathrm{~mm}$ with a smooth surface finish were used for this research work. The chemical composition of the aluminium as per manufacturer Material Safety Data Sheet (MSDS) is shown in Table 1.

Before the welding process, $\mathrm{V}$ grooves with depth of $1.5 \mathrm{~mm}$ and a width of $3 \mathrm{~mm}$ were made on all the aluminium sheets using a milling machine and the titanium carbide particles were filled and compacted into the grooves using a tool with only the shoulder, as illustrated schematically in Figure 1.
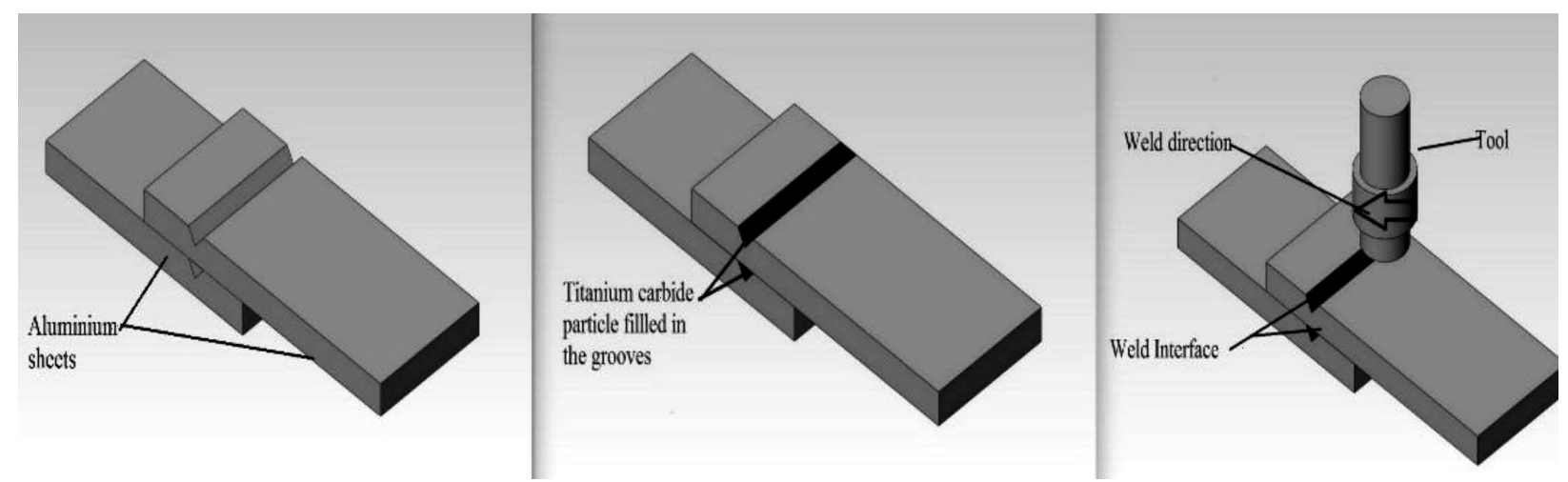

Figure 1: Schematic illustration of FSW of $\mathrm{Al} / \mathrm{TiC}$ Slika 1: Shematski prikaz FSW Al / TiC 
O. O. ABEGUNDE et al.: MICROSTRUCTURAL EVOLUTION AND MECHANICAL CHARACTERIZATIONS OF AL-TiC ...

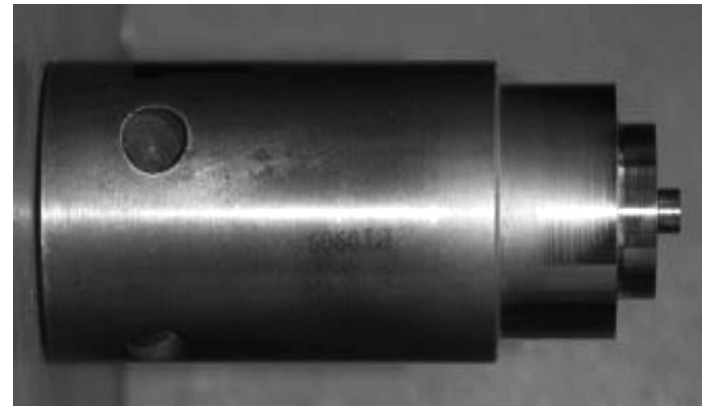

Figure 2: FSW Tool

Slika 2: Orodje za FSW

\subsection{FSW tool}

The FSW tool used is a cylindrical H13 steel tool hardened to 52 HRC shown in Figure 2.

A basic tool geometry was used with a tool length of $5.7 \mathrm{~mm}$ and a tool diameter of $6 \mathrm{~mm}$. The tool shoulder diameter is three times the pin diameter $(18 \mathrm{~mm})$ and with a concave geometry to exert pressure on the workpiece during welding.

\subsection{Friction stir welding platform}

The experimental setup of the samples properly positioned and firmly clamped on the backing plate is shown in Figure 3. The process was performed on an Intelligent Stir Welding for Industry and Research (I-STIR) Process Development System (PDS) at the eNtsa of Nelson Mandela Metropolitan University, Port Elizabeth, South Africa. Table 1 summarizes the different welding parameters used to produce the welds. A tilt angle of $3^{\circ}$ was kept constant and used for all the different welding parameters.

Table 1: FSW process parameters

Tabela 1: FSW-procesni parametri

\begin{tabular}{|c|c|c|c|c|}
\hline $\begin{array}{c}\text { Weld } \\
\text { number }\end{array}$ & $\begin{array}{c}\text { Rotational } \\
\text { speed } \\
\left(\mathrm{min}^{-1}\right)\end{array}$ & $\begin{array}{c}\text { Traverse } \\
\text { speed } \\
(\mathrm{mm} / \mathrm{min})\end{array}$ & $\begin{array}{c}\text { Weld } \\
\text { Interface }\end{array}$ & $\begin{array}{c}\text { Weld pitch } \\
\left(\mathrm{mm} / \mathrm{min}^{-1}\right)\end{array}$ \\
\hline A1 & 1600 & 100 & With TiC & 0.063 \\
\hline A2 & 1600 & 200 & With TiC & 0.125 \\
\hline A3 & 1600 & 300 & With TiC & 0.188 \\
\hline B1 & 1800 & 100 & With TiC & 0.056 \\
\hline B2 & 1800 & 200 & With TiC & 0.111 \\
\hline B3 & 1800 & 300 & With TiC & 0.167 \\
\hline C1 & 2000 & 100 & With TiC & 0.050 \\
\hline C2 & 2000 & 200 & With TiC & 0.100 \\
\hline C3 & 2000 & 300 & With TiC & 0.150 \\
\hline D1 & 1600 & 200 & $\begin{array}{c}\text { Without } \\
\text { TiC }\end{array}$ & 0.125 \\
\hline D2 & 1800 & 200 & $\begin{array}{c}\text { Without } \\
\text { TiC }\end{array}$ & 0.111 \\
\hline D3 & 2000 & 200 & $\begin{array}{c}\text { Without } \\
\text { TiC }\end{array}$ & 0.100 \\
\hline
\end{tabular}

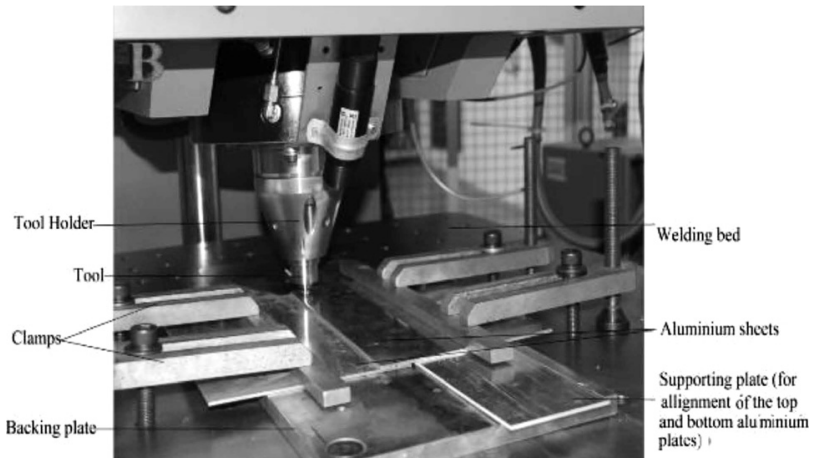

Figure 3: Experimental weld setup of FSW platform

Slika 3: Eksperimentalna postavitev FSW platforme za varjenje

A backing plate made of mild steel was positioned between the bed of the FSW platform and the workpiece. The choice of the backing plate is for a proper dissipation of heat during the welding process. A supporting sheet of the same thickness was placed underneath the upper plate to help align and stabilize the sheets to be joined during welding.

\subsection{Metallographic sample preparation and mechani- cal testing}

Before sectioning the samples for various characterizations with a water-jet cutting machine, the flashes created during welding were removed from the weld seams. The metallographic sample preparation was done in accordance with ASTM E3-95 for microstructure analyses. ${ }^{23}$ The samples were sectioned perpendicular to the weld direction. Grinding and polishing were carefully done on the samples to obtain mirror-finished samples. Keller's reagent was used to etch the samples for the proper observation of the grains. A DP25 Olympus optical microscope and a scanning electron microscope with energy-dispersive spectrometry (SEM + EDS) were used for the microstructural analysis. To evaluate the mechanical properties, Vickers microhardness and Instron tensile testing were used. The Vickers hardness was done in accordance with the ASTM E92-82E3 standard. ${ }^{24}$ A load of $100 \mathrm{~g}$ and a dwell time of 10 seconds were used. The tensile tests were carried out using a load cell capacity of $100 \mathrm{kN}$ at a crosshead rate of $1 \mathrm{~mm} / \mathrm{min}$. No fewer than three lap tests were made for each process parameter. Since there is no test standard for friction stir lap joints, ASTM E8/E8M-13a and ASTM D1002 25,26 for shear strength of a single lap joint adhesively bonded metal specimen (tension loading of metal-to-metal) were used as the reference test standard for the lap shear tests. Fractography was performed on the fractured surface of the tensile samples to determine the mode of failure. 
O. O. ABEGUNDE et al.: MICROSTRUCTURAL EVOLUTION AND MECHANICAL CHARACTERIZATIONS OF AL-TiC ...

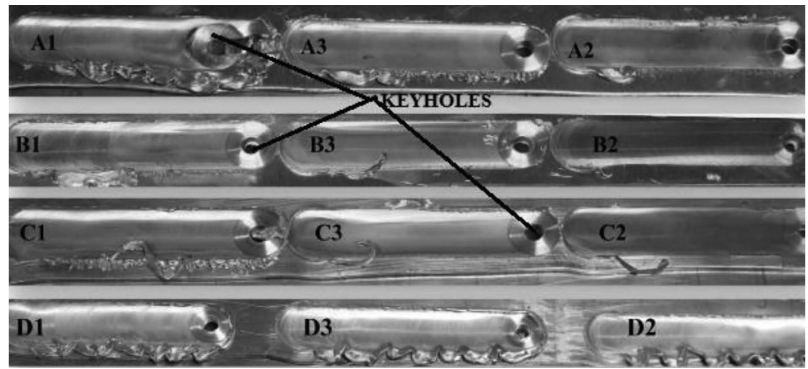

Figure 4: Top view of the processed FSW welds Slika 4: Pogled od vrha na FSW-zvare

\section{RESULTS AND DISCUSSION}

\subsection{Weld surface visual observation}

The top surfaces of the welded samples under different welding process parameters are shown in Figure 4. The samples are labelled according to the designations

Table 2: Macrostructural features for different process parameters Tabela 2: Izgled makrostrukture pri različnih procesnih parametrih

\begin{tabular}{|c|c|c|}
\hline Weld number & Macrostructure & Nugget shape \\
\hline A 1 & & Elliptical \\
\hline $\mathrm{A} 2$ & & Basin \\
\hline A3 & & Basin \\
\hline B1 & & Elliptical \\
\hline B2 & & Elliptical \\
\hline B3 & & Basin \\
\hline $\mathrm{C} 1$ & & Elliptical \\
\hline $\mathrm{C} 2$ & & Basin \\
\hline $\mathrm{C} 3$ & & Basin \\
\hline
\end{tabular}

indicated in Table 1. The visual assessment of the weld surfaces show no typical physical defects like wormholes, cracks or voids.

The shape of the weld seam is slightly convex in nature, which is caused by the design of the tool shoulder. A semi-circular ripple effect caused by the action of the tool shoulder was also observed. This effect is referred to as the wake effect. Keyholes were seen at the end of the weld seam. The depth of these keyholes shows the extent of the penetration of the pin from the top to the bottom sheet. Flashes were observed for all the process parameters used and more on the welds produced without reinforcement particles. Most of the flashes were located on the retreating side of the weld due to the movement of the materials from the advancing side of the weld to the retreating side.

\subsection{Microstructural evolution}

\section{Macrostructure}

Table 2 summarizes the macrostructure pictures at the cross-section of the weld zone for different process parameters.

From Table 2 it is clear that the process parameters have a significant effect on the orientation of the FSP macrostructure. As the traverse speed increased from $100 \mathrm{~mm} / \mathrm{min}$ to $300 \mathrm{~mm} / \mathrm{min}$ using the same tool geometry, the geometry of the nugget zone changed from an elliptical shape to a basin-like shape. It is important to note that the formation of the basin shape is due to the effect of thermal heat transfer from the shoulder of the tool to the sheets. At a high traverse speed of 300 $\mathrm{mm} / \mathrm{min}$, the heat generated is lower and most of the heat built up at the top sheet with a minimal proportion of the heat sink into the bottom sheet. This makes the top sheet undergo more thermal cycles by direct contact with the tool shoulder and severe plastic deformation than the bottom sheet, causing the basin-like shape to form. The intense plastic deformation and high-temperature exposure experienced at the lower traverse speed resulted in the elliptical shape.

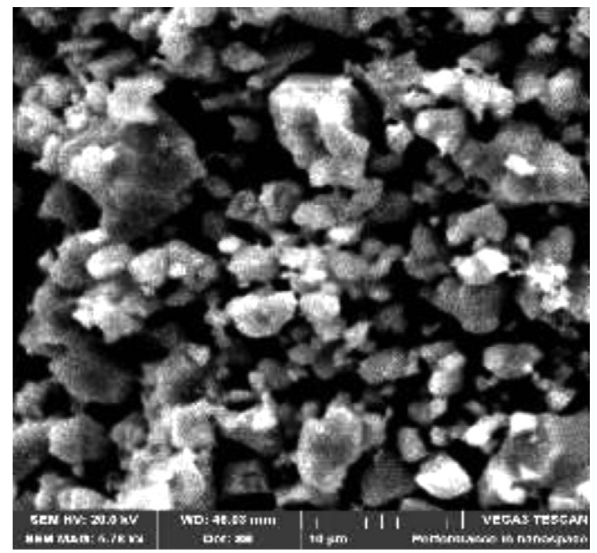

Figure 5: SEM photomicrograph of TiC Powder Slika 5: SEM-posnetek prahu TiC 


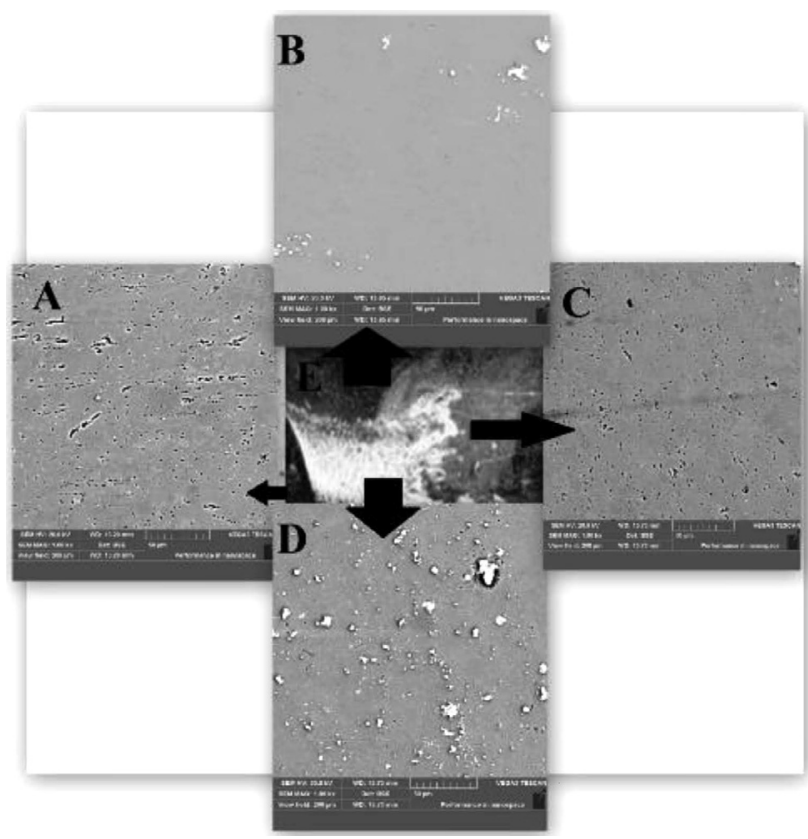

Figure 6: Microstructural evolution at different zones: A) thermomechanical affected zone, B) upper stir zone, C) heat-affected zone, D) lower stir zone E) macrostructure of the weld zone at $2000 \mathrm{~min}^{-1}$ and $300 \mathrm{~mm} / \mathrm{min}$

Slika 6: Razvoj mikrostrukture na različnih področjih: A) termomehansko vplivano področje, B) zgornje mešalno področje, C) toplotno vplivano področje, D) spodnje mešalno področje, E) makrostruktura zvara pri $2000 \mathrm{~min}^{-1}$ in prečni hitrosti $300 \mathrm{~mm} / \mathrm{min}$

\section{TiC Powder}

The micrograph of the TiC powder under the SEM of the $\mathrm{TiC}$ powder used as the reinforcement in this research study is illustrated in Figure 5.

The morphology of the TiC powder is irregular shaped ball milled powder with a grain size of about 2 microns.

\section{Microstructure}

The pictorial overview of the microstructural evolution across different zones after FSP is presented in Figure 6. All the four zones, namely the base metal (BM) close to the heat-affected zone (HAZ), the HAZ that is sandwiched by the BM and the thermo-mechanically affected zone (TMAZ), TMAZ found on both sides of the stir zone (SZ) and the SZ were exhibited in the micrographs taken from the processed zones. The $\mathrm{BM}$ retains its original microstructural features. The TMAZ and HAZ were formed on both the retreating and advancing sides of the welds. The grain structure in the HAZ shows elongated grain growth that is slightly different from the base material. The temperature experienced in the HAZ was enough to thermally activate the grain growth, but not sufficient to plastically deform the grain. In TMAZ, severely deformed grains are found, which are induced by drastic plastic deformation of the SZ during the FSP. In the SZ, the microstructure is characterized by dynamically recrystallized fine equiaxed grains owing to
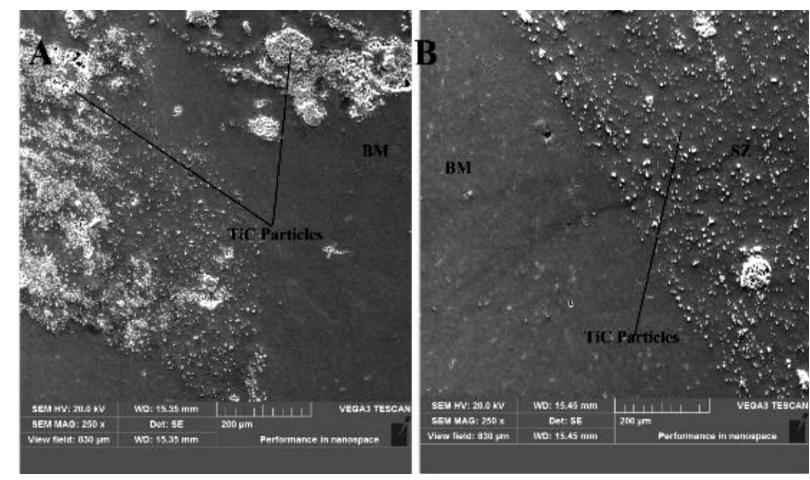

Figure 7: Transition zone: A) retreating side and B) advancing side Slika 7: Prehodno področje: A) umikajoča stran in B) napredujoča stran

the drastic deformation induced by the sufficient stirring during welding of the top and bottom sheets. The distribution of the $\mathrm{TiC}$ reinforcement particles is a salient feature observed between the top and the bottom sheets around the SZ. At the top SZ, the presence of $\mathrm{TiC}$ is negligible and scanty, but a significant distribution was found at the bottom of the sheet. This indicates that during the welding process, the reinforcement particles experienced both downward and horizontal flow around the stir zone. Grains in the upper SZ are coarser than those in the bottom SZ. The heat during the FSP mainly originates from the tool shoulder friction with the surface of the top sheet. Additionally, the heat in the bottom SZ can easily transfer into the bottom sheet and the backing plate. Therefore, the heat cycle of the bottom SZ is relatively lower. The grains in the upper SZ have more time to grow due to the higher heat input.

Another observation from the microstructure is the transition region on the advancing side (AS) and the retreating side (RS), which is illustrated in Figure 7. On the AS, the transition region is sharper and well defined and on the RS, the transition region diffuses into the parent material. On the AS, the plastic deformation direction of the processed zone and the BM are in opposite directions, which resulted in an enormous relative deformation and the homogenous distribution of the $\mathrm{TiC}$ particles between the BM and the processed zone at the AS, but the BM distorted and diffused smoothly together with the processed zone at the RS, resulting in clustering of the reinforcement.

It can be observed that the $\mathrm{TiC}$ reinforcement within the processed zone had undergone intense mixing and stirring, resulting in breakup of the coarse TiC morphology. As the rotational speed of the weld increased from $1600 \mathrm{~min}^{-1}$ to $2000 \mathrm{~min}^{-1}$, the distribution of $\mathrm{TiC}$ becomes more homogenous, as shown in Figure 8. At a rotational speed of $1600 \mathrm{~min}^{-1}$, the particles clustered together around the bottom sheet and at $2000 \mathrm{~min}^{-1}$, the particles were uniformly distributed around the stir zone.

The contribution of intense deformation and hightemperature exposure within the stir zone resulted in 
O. O. ABEGUNDE et al.: MICROSTRUCTURAL EVOLUTION AND MECHANICAL CHARACTERIZATIONS OF AL-TiC ...
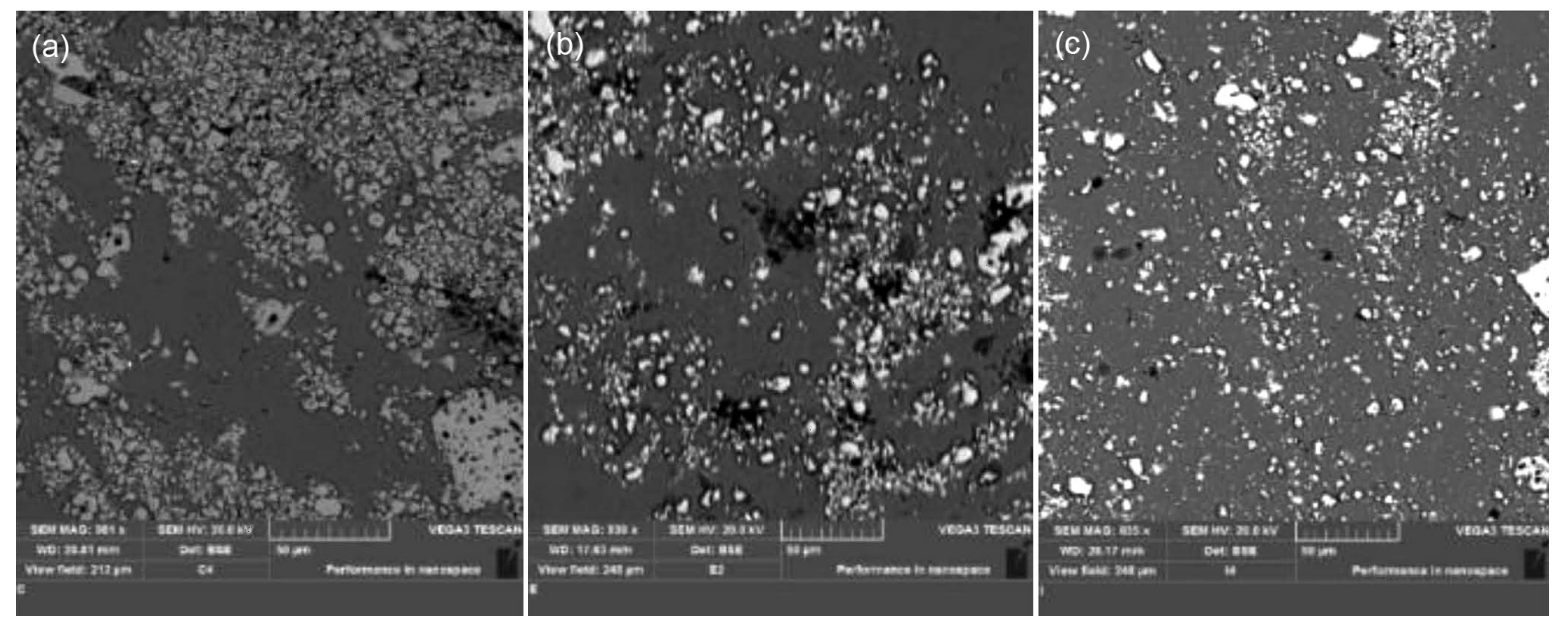

Figure 8: SEM micrograph at a traverse speed of $100 \mathrm{~mm} / \mathrm{min}$ and rotational speeds of: a) $1600 \mathrm{~min}^{-1}$ b) $1800 \mathrm{~min}^{-1}$ and c) $2000 \mathrm{~min}^{-1}$ Slika 8: SEM posnetek pri prečni hitrosti $100 \mathrm{~mm} / \mathrm{min}$ in hitrosti vrtenja: a) $1600 \mathrm{~min}^{-1}$, b) $1800 \mathrm{~min}^{-1}$ in c) $2000 \mathrm{~min}^{-1}$

fragmentation, recrystallization and the development of refined texture within and around the stir zone at a rotational speed of $2000 \mathrm{~min}^{-1}$. In addition, an increase in the traverse speed caused the particles to agglomerate in the stir zone. As the traverse speed decreased, the grain size also decreased in the composite but increased in the pure aluminium samples without the reinforcement. This might be due to the high heat input associated with the low traverse speed. The significant effect of particle reinforcement on the grain size refinement of the matrix is reported as a pinning effect. According to the pinning effect, the grain refinement by reinforcement particles increases with a decrease in the particle size and an increase in the volume fraction of the particles. Sufficient heat input and stirring are responsible for the deformation and recrystallization of the matrix with the reinforcement. At a higher rotational speed of 2000 $\mathrm{min}^{-1}$ and a traverse speed of $100 \mathrm{~mm} / \mathrm{min}$, a more uniform distribution of the TiC particles was found.

Energy Dispersive Spectroscopy Results

EDS analyses were performed on all the welds with reinforcement. The uniformly distributed particles were

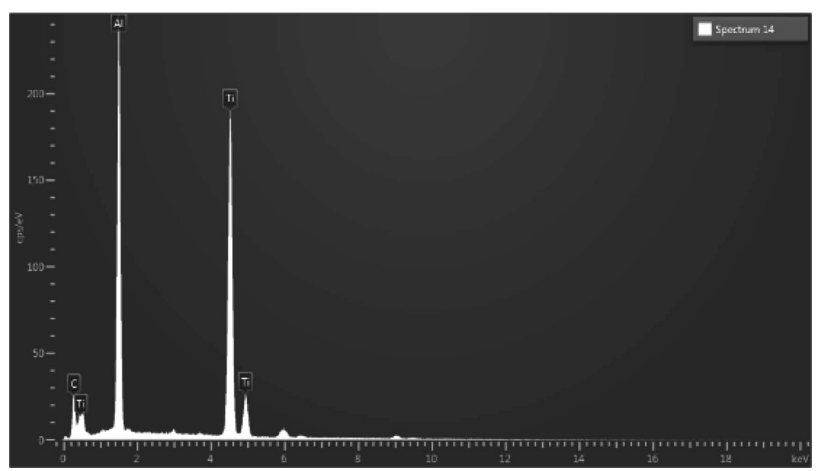

Figure 9: EDS from the weld interface at a rotational speed of 2000 $\mathrm{min}^{-1}$ and a traverse speed of $100 \mathrm{~mm} / \mathrm{min}$

Slika 9: EDS iz stika z zvarom pri hitrosti vrtenja $2000 \mathrm{~min}^{-1}$ in prečni hitrosti $100 \mathrm{~mm} / \mathrm{min}$ confirmed to be titanium and carbon, as shown in Figure 9, which is a scan of the weld interface of the sample produced at a rotational speed of $2000 \mathrm{~min}^{-1}$ and a traverse speed of $100 \mathrm{~mm} / \mathrm{min}$.

The elemental composition by atomic weight at the stir zone is confirmed to be $72.04 \%$ of aluminium, $23.71 \%$ of carbon and $4.34 \%$ of titanium.

\subsection{Microhardness Profiling}

The Vickers hardness distribution is illustrated in Figure 10. The shape of the hardness distribution is a "W-sinusoidal". The lowest hardness value was found at the HAZ and the highest hardness value at the SZ. The hardness value of the SZ increased by $58 \%$ when compared to the base metal for sample C1. Thangarasu ${ }^{21}$ suggested four methods of hardening in FSW MMC:

- Orowan strengthening.

- Grain and substructure strengthening.

- Quench hardening resulting from the dislocations generated to accommodate the differential thermal contraction between the reinforcing particles and the matrix.

- Work hardening due to the strain misfit between the elastic reinforcing particles and the plastic matrix.

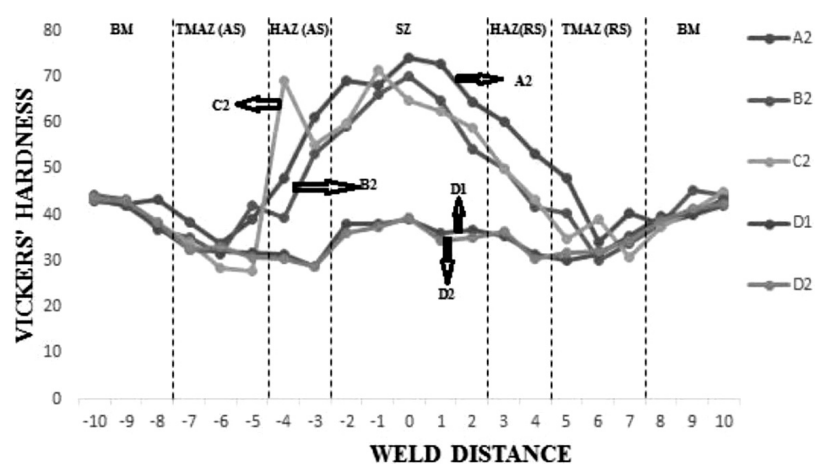

Figure 10: Hardness profile of the FSL welds

Slika 10: Profil trdote preko FSL-zvarov 
O. O. ABEGUNDE et al.: MICROSTRUCTURAL EVOLUTION AND MECHANICAL CHARACTERIZATIONS OF AL-TiC ...

Table 3: Shear strength and joint efficiency of the welds

Tabela 3: Strižna trdnost in skupna učinkovitost različnih zvarov

\begin{tabular}{|c|c|c|c|c|c|}
\hline Weld number & $\begin{array}{c}\text { Rotational speed } \\
\left(\mathrm{min}^{-1}\right)\end{array}$ & $\begin{array}{c}\text { Traverse speed } \\
(\mathrm{mm} / \mathrm{min})\end{array}$ & $\begin{array}{c}\text { Weld pitch } \\
(\mathrm{mm} / \mathrm{min})\end{array}$ & $\begin{array}{c}\text { Average shear fracture } \\
\text { load per unit width } \\
(\mathrm{N} / \mathrm{mm})\end{array}$ & $\begin{array}{c}\text { Joint efficiency } \\
(\%)\end{array}$ \\
\hline A1 & 1600 & 100 & 0.063 & $\mathbf{1 5 9}$ & 79.4 \\
\hline A2 & 1600 & 200 & 0.125 & $\mathbf{1 5 0}$ & 60.8 \\
\hline A3 & 1600 & 300 & 0.188 & $\mathbf{1 3 2}$ & 52.97 \\
\hline B1 & 1800 & 100 & 0.056 & $\mathbf{1 8 5}$ & 90.51 \\
\hline B2 & 1800 & 200 & 0.111 & $\mathbf{1 7 8}$ & 77.53 \\
\hline B3 & 1800 & 300 & 0.167 & $\mathbf{1 7 0}$ & 68.60 \\
\hline C1 & 2000 & 100 & 0.050 & $\mathbf{2 1 8}$ & 92.14 \\
\hline C2 & 2000 & 200 & 0.100 & $\mathbf{2 1 3}$ & 85.96 \\
\hline C3 & 2000 & 300 & 0.150 & $\mathbf{1 7 5}$ & 69.44 \\
\hline D1 & 1600 & 200 & 0.125 & $\mathbf{2 0 1}$ & 81.67 \\
\hline D2 & 1800 & 200 & 0.111 & $\mathbf{1 8 7}$ & 81.45 \\
\hline D3 & 2000 & 200 & 0.100 & $\mathbf{1 7 3}$ & 69.81 \\
\hline
\end{tabular}

The increment in the hardness value at the $\mathrm{SZ}$ is attributed to grain refinement and the presence of reinforcement particles. The fragmentation of larger $\mathrm{TiC}$ particles gave rise to dislocation density and dynamic recrystallization during welding, thereby producing a finer grain size in the stir zone. These factors are responsible for higher hardness values in the stir zone of welds with the reinforcement particles. The minimum hardness value appeared at the HAZ. This is due to the thermal history experienced at this zone, which resulted in the coarsening of the precipitates.

Because of the distribution and the deposition of the TiC particles around the AS of the welded zone, the AS size shows higher hardness values than the RS due to the fact that materials on the RS have a shorter time to rotate since the current flow of material is directly proportional to the time of flow on this side.

\subsection{Tensile behaviour}

In order to quantify the mechanical resistance of the FSWed joints, the ratio between the maximum transferred load by the specimens in shear test to the width of the specimen itself was considered. In this way, the values are shown for all the considered cases. The average results of the three replica samples carried out are reported. Every sample was tested to failure. The shear fracture load per unit width of the FSWed Al with and without the $\mathrm{TiC}$ composite for different process parameters are presented in Table 3.

From the results obtained, it was found that the maximum shear strength was observed at a rotational speed of $2000 \mathrm{~min}^{-1}$ and a traverse speed of 100 $\mathrm{mm} / \mathrm{min}$, and the minimum was observed at a rotational speed of $1600 \mathrm{~min}^{-1}$ and a traverse speed of 300 $\mathrm{mm} / \mathrm{min}$. Both the maximum and the minimum shear strengths were observed when the TiC reinforcement particles were added, but at different rotational and traverse speeds, respectively. It can be concluded from the results that the relationship between the fracture load and the traverse speed is inversely proportional. An increase in the traverse speed causes the fracture load to decrease. A shorter reaction time and a lower reaction temperature are associated with a higher traverse speed and this led to a decrease in the stirring period and the vertical movement of the material with the reinforcement, thereby affecting the strength of the bonding at the interface. It is obvious that the fracture load increases with an increase in the rotational speed for all the samples with reinforcement. As the rotational speed increased from $1600 \mathrm{~min}^{-1}$ to $2000 \mathrm{~min}^{-1}$, a substantial increase in the fracture load was observed. A higher rotational speed generated a higher heat input because of the higher friction heating, which resulted in more intense stirring and mixing of the material.

It should be noted that the fracture load behaviour that occurred in the samples without reinforcement is the reciprocal of results obtained from the samples with reinforcement. The absence of the ceramic particle along the path of the weld seam exposed the weld interface to a higher degree of thermal reaction, thereby making it sensitive to temperature changes. As the rotational speed increases, the temperature around the weld zone in-

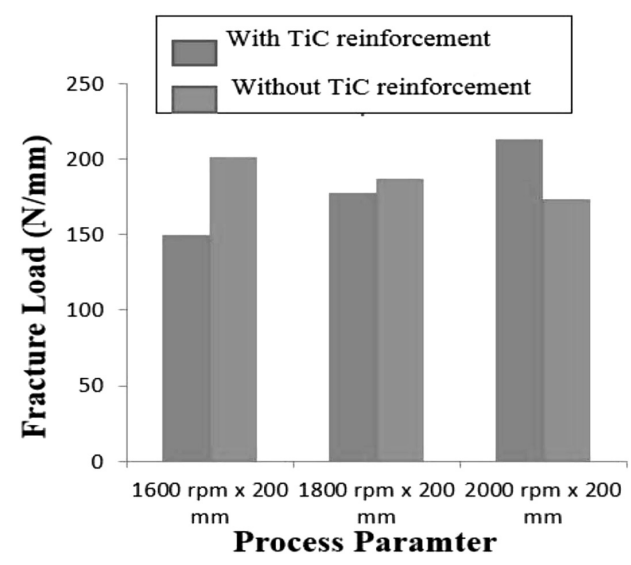

Figure 11: Fracture load against the process parameters

Slika 11: Odvisnost obremenitve pri porušitvi od parametrov procesa 


\section{MATERIALI IN TEHNOLOGIJE/MATERIALS AND TECHNOLOGY (1967-2017) - 50 LET/50 YEARS}

\section{O. O. ABEGUNDE et al.: MICROSTRUCTURAL EVOLUTION AND MECHANICAL CHARACTERIZATIONS OF AL-TiC ...}

creases, causing a highly turbulent mixture and stirring of the materials. Since there is no intermediate particle to balance the temperature change, the strength of the bonding will be compromised. However, once a sufficient rotational speed is achieved, a further increase is not beneficial to the mechanical properties for welds produced without reinforcement particles.

Figure 11 shows the effect of the reinforcement particles on the fracture load. As can be seen, the presence of the TiC reinforcement particles contributed an appreciable strength change to the fracture load at a higher rotating speed of $2000 \mathrm{~min}^{-1}$ and does not show a remarkable improvement in the fracture load at rotational speeds of $1600 \mathrm{~min}^{-1}$ and $1800 \mathrm{~min}^{-1}$, respectively, instead, it had an inverse effect on the strength.

At a rotational speed of $2000 \mathrm{~min}^{-1}$, the $\mathrm{TiC}$ homogenously mixed with the Al alloy properly, thereby forming a well-bonded matrix that yielded a higher fracture strength. The presence of the ceramic particles constrained the easy failure of the material when under loading, thereby improving the mechanical strength of the matrix.

\section{Joint efficiency}

To estimate the joint efficiency of the FS welds, the ratios of the tensile strength of the lap shear specimens were compared to the tensile strength of the base metals. According to studies, ${ }^{27}$ the tensile strength of the lap shear specimen is derived from the fracture load per unit width to the effective sheet thickness (EST) as shown in Equation (1):

Tensile strenth of $=$ Fracture load per unit width lap shear specimen $=\frac{\text { EST }}{\text { laction }}$

The EST is defined as the minimum sheet thickness determined by measuring the smallest distance between any un-bonded interface and the top surface of the upper sheet or the bottom surface of the lower sheet and it varies with the process parameter, depending on the degree of bonding that exists between the weld interfaces. These phenomena should have apparent influences on

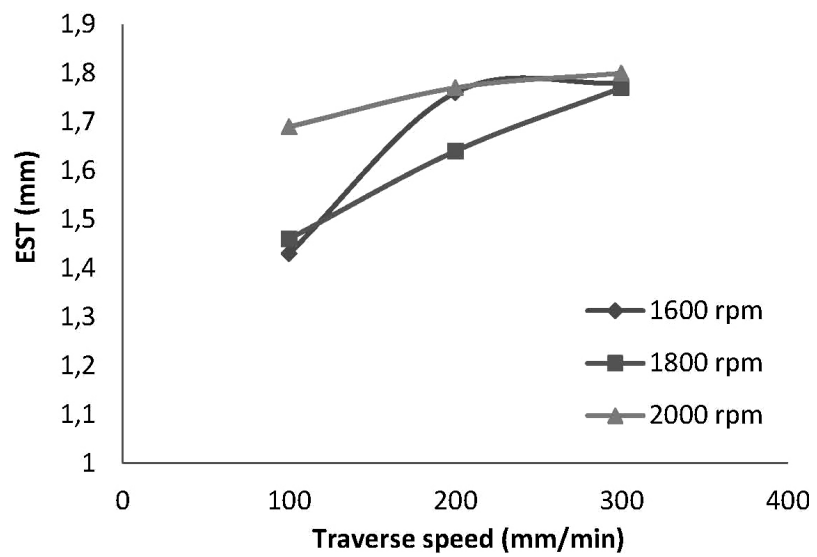

Figure 12: EST against the traverse speed

Slika 12: Odvisnost med EST in prečno hitrostjo the bearing load of FSW lap-welded joints. Also presented in Table 3 is the joint efficiency of the processed samples for different process parameters. From the result, the joint efficiency ranges from $52 \%$ to $92 \%$. The highest was found at a rotational speed of $2000 \mathrm{~min}^{-1}$ and a traverse speed of $100 \mathrm{~mm} / \mathrm{min}$.

The effect of the traverse speed on the EST was studied. Figure 12 shows the graphical relationship between the EST versus traverse speed. The traverse speed exhibits a linear relationship with the EST. As the traverse speed increased, the dimension of the EST also increased, thereby reducing the area of the metallurgical bond that exists at the processed interface. Since the strength of the weld interface depends on the area of the metallurgical bond during the welding process, it is apparent that the relationship between the EST and the overall strength of the processed zone is exponential.

\section{Fracture behaviour}

Four different modes of failure were observed at the joint interfaces, as illustrated in Figure 13. They are the fracture mode (FM) 1, the shear fracture that occurred due to a lack of joint formation along the original inter-
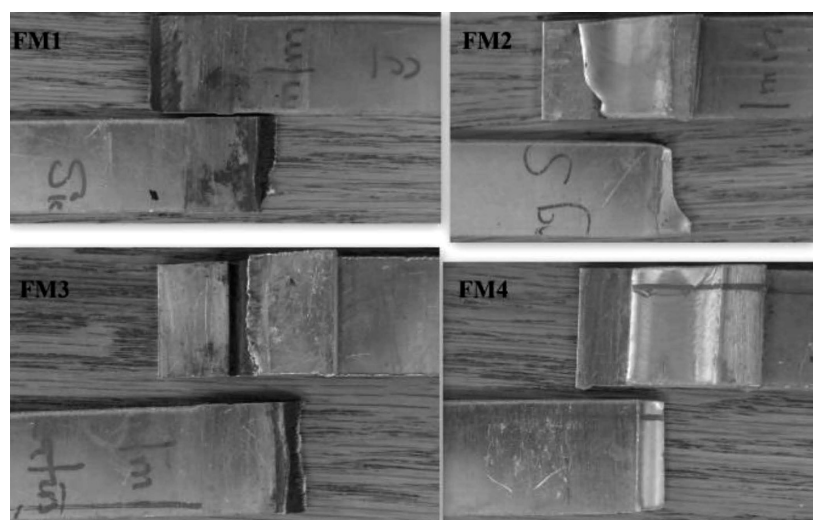

Figure 13: Fracture mode of the welded samples for different process parameters

Slika 13: Način zloma vzorcev, zvarjenih pri različnih procesnih parametrih

Table 4: Mode of fracture for different process parameters

Tabela 4: Način zloma pri različnih procesnih parametrih

\begin{tabular}{|c|c|c|c|}
\hline Weld number & $\begin{array}{c}\text { Rotational } \\
\text { speed }\left(\mathrm{min}^{-1}\right)\end{array}$ & $\begin{array}{l}\text { Traverse speed } \\
(\mathrm{mm} / \mathrm{min})\end{array}$ & Fracture mode \\
\hline A1 & 1600 & 100 & FM 1/FM 2 \\
\hline A2 & 1600 & 200 & FM 2 \\
\hline $\mathrm{A} 3$ & 1600 & 300 & FM 1 \\
\hline B1 & 1800 & 100 & FM 3 \\
\hline B2 & 1800 & 200 & FM 3 \\
\hline B3 & 1800 & 300 & FM 4 \\
\hline $\mathrm{C} 1$ & 2000 & 100 & FM 3/FM 4 \\
\hline $\mathrm{C} 2$ & 2000 & 200 & FM 3 \\
\hline $\mathrm{C} 3$ & 2000 & 300 & FM 4 \\
\hline D1 & 1600 & 200 & FM 3 \\
\hline D2 & 1800 & 200 & FM 4 \\
\hline D3 & 2000 & 200 & FM 4 \\
\hline
\end{tabular}



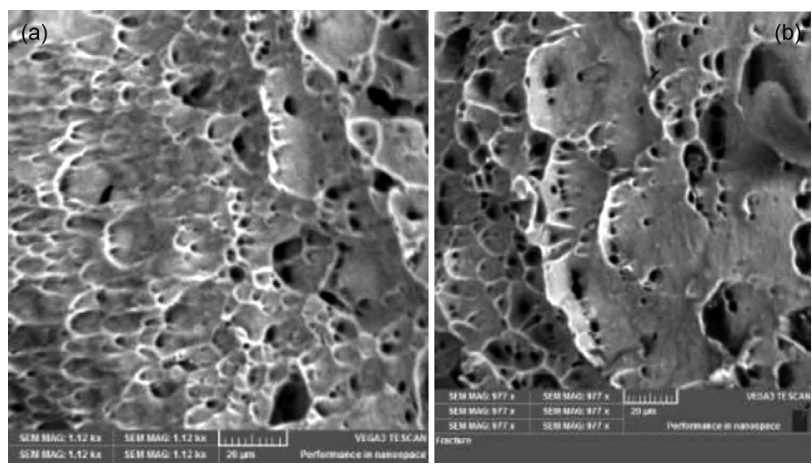

Figure 14: SEM images of the fracture surface for the weld produced at a rotational speed of $2000 \mathrm{~min}^{-1}$ and a traverse speed of $100 \mathrm{~mm} / \mathrm{min}$ Slika 14: SEM-posnetek površine preloma zvara, izdelanega pri hitrosti vrtenja $2000 \mathrm{~min}^{-1}$ in prečni hitrosti $100 \mathrm{~mm} / \mathrm{min}$

face of the two sheets. This led to a pseudo metallurgical bond between the two sheets and the bond shear under tensile loading. Fracture mode 2 occurred on the advancing size hooking in which the crack initiates from the tip of the hook on the AS, propagates upward along the SZ/TMAZ interface and finally, the fracture at the SZ. Fracture mode 3 was noticed on the retreating side softening initiated from the hook and then linked to the pores on the bottom plates caused by the diffusion of the bottom plate with the backing plate. The crack follows the sharp end of the grove to the other end. Fracture mode 4 failure took place close to the base metal, but the weld actually failed at the HAZ on the advancing side of the weld. Table 4 lists the failure modes observed for each process parameter combination.

FM 1 was found at a low rotational speed of 1600 $\mathrm{min}^{-1}$ and a high traverse speed of $300 \mathrm{~mm} / \mathrm{min}$. The dominant fracture modes are FM 3 and FM 4.

FM 1 is observed at a low rotational speed and high traverse speed. This process condition is associated with the low heat input that resulted in insufficient deformation and a flow of the material forming the pseudo weld. The crack initiation occurs through the gap tip of the unwelded area and went through the stir zone, making the weld shear into two at the welded area. This usually occurs when an insufficient metallurgical bond is formed between the sheets.

FM 2 and FM 3 are the most dominating failure modes. The fracture mode is similar to the normal tensile behaviour of the aluminium alloy. The material went through necking for a period before eventually fracturing at the weakest zone.

The SEM images of the fracture surfaces were taken to determine the mode of fracture. Figure 14 illustrates the typical fractography features of the failure surfaces.

The morphology of the failure mode shows a large number of fine dimples, which confirms the amount of plastic flow prior to the failure under tensile loading. The fine dimple features observed indicate that the behaviour of the fracture is ductile, which implies that the lap joints exhibited ductile fracture during the lap shear tests.

\section{CONCLUSION}

Based on the observations from the results, the followings conclusions can be drawn:

- The microstructural evolution correlates with the process parameters employed to produce the welds in this study. It was found that as the traverse speed increases, the evolving microstructure changed from elliptical to a basin-like shape at the interface.

- The microstructure revealed that the majority of the TiC particles were transported from the weld interface and deposited in the bottom sheet.

- The highest tensile value of $218 \mathrm{~N} / \mathrm{mm}$ and the joint efficiency of $92 \%$ were recorded for a weld produced at a high rotational speed of $2000 \mathrm{~min}^{-1}$ and a low traverse speed of $100 \mathrm{~mm} / \mathrm{min}$. This parameter combination setting can be recommended.

- The maximum hardness occurred at the stir zone and the minimum at the HAZ. The advancing side exhibited a higher hardness distribution compared to the retreating side of the welds.

\section{Acknowledgements}

Mr Abegunde (co-author) would like to acknowledge the University of Johannesburg under the Global Excellence Stature (GES) award scholarship of the Postgraduate Research Centre for their financial support, Prof Esther Akinlabi (co-author) acknowledges the Johannesburg Institute of Advanced Study (JIAS) for the writing fellowship award during which she was able to contribute to this manuscript and finally, the eNtsa Research Group of Nelson Mandela Metropolitan University (NMMU), Port Elizabeth, South Africa is acknowledged for allowing us to use their facility to produce the welds.

\section{REFERENCES}

${ }^{1}$ R. Mishra, Z. Ma, Friction stir welding and processing. Materials Science and Engineering: R: Reports 50 (2005) 1, 1-78, doi:10.1016/ j.mser.2005.07.001

${ }^{2}$ K. Kainer, Metal matrix composites: Custom-made materials for automotive and aerospace engineering. John Wiley \& Sons, 2006

${ }^{3}$ Fabrication of near-net shape graphite/magnesium composites for large mirrors, Orlando'90, International Society for Optics and Photonics, 1990, 16-20

${ }^{4}$ D. Miracle, Metal matrix composites-from science to technological significance, Composites Sci. Technol. 65 (2005) 15, 2526-40, doi:10.1016/j.compscitech.2005.05.027

${ }^{5} \mathrm{~S}$. Rawal, Metal-matrix composites for space applications, Journal of Minerals, Metals and Materials Society, 53 (2001) 4, 14-7, doi:10.1007/s11837-001-0139-z

${ }^{6}$ L. Santo, D. Paulo, Surface engineering techniques and applications: Research Advancements, 2014, 1-347

${ }^{7}$ P. Babalola, C. Bolu, A. Inegbenebor, K. Odunfa, Development of aluminium matrix composite, International Journal of Engineering and Technology Research, 2 (2014) 1, 1-11 


\section{MATERIALI IN TEHNOLOGIJE/MATERIALS AND TECHNOLOGY (1967-2017) - 50 LET/50 YEARS}

\section{O. O. ABEGUNDE et al.: MICROSTRUCTURAL EVOLUTION AND MECHANICAL CHARACTERIZATIONS OF AL-TiC ...}

${ }^{8}$ W. Thomas, E. Nicholas, J. Needham, M. Murch, P. Temple Smith C. Dawes, Inventors, Friction stir welding, UK Patent Office, London patent, December 6, 1991 .

${ }^{9}$ D. Klobcar, L. Kosec, A. Pietras, A. Smolej, Friction-stir welding of aluminium alloy 5083, Mater. Tehnol., 46 (2012) 5, 483-488

${ }^{10}$ S. Kastelic, J. Tušek, D. Klobčar, J. Medved, P. Mrvar, AA4130 and AA1050 Joined with friction-stir welding, Mater. Tehnol., 47 (2013) 2, 195-198

${ }^{11}$ R. Palanivel, P. Mathews, The tensile behaviour of friction-stirwelded dissimilar aluminium alloys, Mater. Tehnol., 45 (2011) 6 , 623-626

${ }^{12}$ E. Akinlabi, Characterisation of dissimilar friction stir welds between 5754 aluminium alloy and C11000 copper, Dissertation submitted to Nelson Mandela Metropolitan University, Port Elizabeth, South Africa 2011

${ }^{13}$ D. Sanders, Development of friction stir welding combined with superplastic forming processes for the fabrication of titanium structures. Dissertation submitted to University of Washington, Washington, United States 2008

${ }^{14}$ A. Elrefaey, M. Gouda, M. Takahashi, K. Ikeuchi, Characterization of aluminum/steel lap joint by friction stir welding, 2004

${ }^{15}$ R. Mishra, Z. Ma, I. Charit, Friction stir processing: A novel technique for fabrication of surface composite. Materials Science and Engineering, 341 (2003) 1, 307-310, doi:10.1016/S0921-5093(02) 00199-5

${ }^{16} \mathrm{Z}$. Ma, Friction stir processing technology: A review. Metallurgical and Materials Transactions, 39 (2008) 3, 642-658, doi:10.1007/ s11661-007-9459-0

${ }^{17}$ A. Smolej, D. Klobčar, B. Skaza, A. Nagode, E. Slaček, V. Dragojević, S. Smolej, The superplasticity of friction stir processed al-5Mg alloy with additions of scandium and zirconium, International Journal of Materials Research, 105 (2014) 12, 1218-1226, doi:10.3139/146.111141

${ }^{18}$ A. Smolej, Superplastic behaviour of AA5083 aluminium alloy with scandium and zirconium, Materials Science ForumTrans Tech Publ, 2012, doi:10.4028/www.scientific.net/MSF.706-709.395
${ }^{19}$ V. Sharma, U. Prakash, B. Kumar, Surface composites by friction stir processing: A review, J Mater Process Technology, vol. 706-709, 2015,395

${ }^{20}$ E. Akinlabi, R. Mahamood, S. Akinlabi, E. Ogunmuyiwa, Processing parameters influence on wear resistance behaviour of friction stir processed al-TiC composites, Advances in Materials Science and Engineering, 2014, doi:10.1155/2014/724590

${ }^{21}$ A. Thangarasu, N. Murugan, I. Dinaharan, S. Vijay, Microstructure and microhardness of AA1050/TiC surface composite fabricated using friction stir processing, Sadhana 37 (2012) 5, 579-586, doi:10.1007/s12046-012-0097-x

${ }^{22}$ S. Jerome, S. Bhalchandra, S. Babu, B. Ravisankar, Influence of microstructure and experimental parameters on mechanical and wear properties of al-TiC surface composite by FSP route, Journal of Minerals and Materials Characterization and Engineering, 11 (2012) 05, 488-493, doi:10.4236/jmmce.2012.115035

${ }^{23}$ Standard A. E3, standard guide for preparation of metallographic specimens, ASTM International, West Conshohocken, PA 2001

${ }^{24}$ Standard A. E92-82 E3. 1997: Standard test method for vickers hardness of metallic materials, Annual Book of ASTM Standards, ASTM International, West Conshohocken, PA ASTM

${ }^{25}$ Standard A. D1002-01, 2001, Standard Test Method for Apparent Shear Strength of Single-Lap-Joint Adhesively Bonded Metal Specimens by Tension Loading (Metal-to-Metal), ASTM International, West Conshohocken, PA, 2001, doi:10.1520/D1002-10.

${ }^{26}$ Standard A. E8/E8M-13a, standard test method for determining volume fraction by systematic manual point, ASTM International, West Conshohocken, PA 2013

${ }^{27}$ X. Xu, X. Yang, G. Zhou, J. Tong, Microstructures and fatigue properties of friction stir lap welds in aluminum alloy AA6061-T6, Journal of Materials and Design 35 (2012) 5, 175-83, doi:10.1016/ j.matdes.2011.09.064 